\title{
IgE sensitisation predicts threshold but not anaphylaxis during oral food challenges to cow's milk
}

\author{
Paul Turner ${ }^{1}$, Bettina Duca ${ }^{1}$, Sophia Chastell A ${ }^{1}$, Olaya Alvarez ${ }^{2}$, Raphaelle Bazire ${ }^{3}$, \\ Marta Vazquez-Ortiz ${ }^{1}$, and Pablo Rodriguez del Rio ${ }^{3}$ \\ ${ }^{1}$ Imperial College London \\ ${ }^{2}$ Complexo Hospitalario Universitario A Coruna \\ ${ }^{3}$ Hospital Infantil Universitario Nino Jesus
}

November 10, 2021

\begin{abstract}
Predicting reaction threshold and severity are important to improve the management of food allergy, however the determinants of, and relationship between, these parameters are significant knowledge gaps. Identifying robust predictors could enable the reliable risk-stratification of food-allergic individuals. In this series of young people with CM-allergy undergoing DBPCFC - the largest reported in the literature - we did identify any baseline marker which predicted the occurrence of anaphylaxis at challenge, consistent with existing data. 1 There is one report of IgE-sensitisation being predictive of severity in CMallergy, ${ }^{5}$ however the authors included non-reactive patients in their analysis which significantly skewed the analyses, resulting in misleading conclusions. ${ }^{6}$ IgE-sensitisation in our cohort, particularly to casein, was predictive of LOAEL. Including an assessment of casein IgE may therefore be of clinical utility when evaluating patients with CM-allergy in the clinical setting.
\end{abstract}

\section{TITLE PAGE}

\section{LETTER TO THE EDITOR}

IgE sensitisation predicts threshold but not anaphylaxis during oral food challenges to cow's milk

Paul J. Turner ${ }^{*}$, Bettina Duca ${ }^{1}$, Sophia A Chastell ${ }^{1}$, Olaya Alvarez $^{2}$, Raphaëlle Bazire ${ }^{3}$, Marta VazquezOrtiz $^{1}$, Pablo Rodríguez del Río ${ }^{3}$

\section{Affiliations:}

${ }^{1}$ National Heart \& Lung Institute, Imperial College London, London, UK;

${ }^{2}$ Complexo Hospitalario Universitario de Ferrol, A Coruña, Spain;

${ }^{3}$ Department of Allergy, Hospital Infantil Universitario Niño Jesus, Madrid; Health Research Institute Princesa, Madrid, Spain; ARADyAL Research Network;

\section{*Corresponding author:}

Dr Paul Turner

National Heart \& Lung Institute,

Imperial College London,

Norfolk Place

London, W2 1PG 
Tel: $+44(0) 2033127754$

Email: p.turner@imperial.ac.uk

Word Count : 602 words

\section{Key words}

Allergy, anaphylaxis, cow's milk, eliciting dose, food challenge, lowest observed adverse effect level, thresholds.

To the Editor:

There are increasing data relating to predicting the outcomes of oral food challenges (FC) to peanut, specifically severity of reaction and eliciting dose. ${ }^{1}$ However, data are more limited for other allergens such as cow's milk (CM) protein, particularly in older children and teenagers with persisting allergy to CM. Given that CM is a major cause of severe and even fatal allergic reactions, ${ }^{1}$ this is a significant knowledge gap. We therefore analysed predictors of severity and eliciting dose in young people undergoing double-blind placebo-controlled food challenges (DBPCFC) to CM in the SOCMA study (Clinicaltrials.gov NCT02216175).

We recruited children and young people aged 6-18 years with a clinical history of CM-allergy, presenting for clinical review in our hospitals. Exclusion criteria were: medically unfit for challenge (e.g. high fever or intercurrent illness); acute wheeze or poorly controlled asthma; oral corticosteroids within 14 days of FC; anaphylaxis in the 4 weeks prior to FC (to exclude patients in an anergic state); antihistamines within 5 days of FC. Subjects with a history of prior anaphylaxis were not excluded. The study was approved by the NHS Human Research Authority (reference 18/LO/1070) and the Hospital Infantil Universitario Niño Jesus Ethics Committee (reference R0003/17). Written informed consent was obtained for all participants.

98 participants (median age 10 years) were screened, of whom 93 underwent DBPCFC. The first challenge dose was $0.5 \mathrm{mg}$ CM protein (or tapioca starch as placebo, dissolved in rice "milk" with Nesquik@ flavouring) followed by a 60 minute observation period. Subsequent doses were given every 20-30 minutes, according to the following schedule: $3 \mathrm{mg}, 10 \mathrm{mg}, 30 \mathrm{mg}, 100 \mathrm{mg}, 300 \mathrm{mg}, 1000 \mathrm{mg}$ and $3000 \mathrm{mg}$ of CM protein (or placebo), until stopping criteria (PRACTALL) were met. Eliciting dose was defined as the lowest observed adverse effect level (LOAEL) triggering objective symptoms. ${ }^{2} 83$ subjects $(89 \%)$ reacted with objective symptoms at challenge, of whom 16 (19\%) had anaphylaxis (WAO 2020 criteria) (Table S1). The median cumulative eliciting dose (cumED) was 143.5mg (IQR 43.5-443.5mg) CM protein.

Baseline markers of sensitisation and other relevant information are shown in Table 1. We did not identify any significant predictors for the occurrence of anaphylaxis at OFC. There was a moderate and significant correlation between specific IgE to CM protein/casein (both skin prick test (SPT) and serum $\operatorname{IgE}$ ) and LOAEL $(\mathrm{p}<0.0001)$. At multivariate analysis, both SPT and serum IgE to casein were predictive of LOAEL $(\mathrm{p}=0.007$ and $\mathrm{p}=0.018$, respectively; Table S2). Population dose distributions were determined as previously described, ${ }^{3}$ using an Interval-Censoring Survival Analysis (ICSA) approach in R (v4.1.2, survival package v3.2-13). The cumulative eliciting dose predicted to provoke reaction in $5 \%$ of the population $\left(\mathrm{ED}_{05}\right)$ was 2.5mg (95\% CI 1.1-6.0) and 2.7mg (95\%CI 1.2-6.1) CM protein, estimated using Log-Normal and Log-Logistic parametric models respectively. The dose-distributions are plotted in Figure 1, and are not dissimilar to existing data for LOAEL to CM protein in allergic individuals. ${ }^{4}$

Predicting reaction threshold and severity are important to improve the management of food allergy, however the determinants of, and relationship between, these parameters are significant knowledge gaps. Identifying robust predictors could enable the reliable risk-stratification of food-allergic individuals. In this series of young people with CM-allergy undergoing DBPCFC - the largest reported in the literature - we did identify any baseline marker which predicted the occurrence of anaphylaxis at challenge, consistent with existing data. ${ }^{1}$ There is one report of IgE-sensitisation being predictive of severity in CM-allergy, ${ }^{5}$ however the authors included non-reactive patients in their analysis which significantly skewed the analyses, resulting in misleading conclusions. ${ }^{6}$ IgE-sensitisation in our cohort, particularly to casein, was predictive of LOAEL. 
Including an assessment of casein IgE may therefore be of clinical utility when evaluating patients with CM-allergy in the clinical setting.

Paul J. Turner ${ }^{1}$

Bettina Duca ${ }^{1}$

Sophia A Chastell ${ }^{1}$

Olaya Alvarez ${ }^{2}$

Raphälle Bazire ${ }^{3}$

Marta Vazquez-Ortiz ${ }^{1}$

Pablo Rodríguez del Río ${ }^{3}$

\section{Affiliations:}

${ }^{1}$ National Heart \& Lung Institute, Imperial College London, London, UK;

${ }^{2}$ Complexo Hospitalario Universitario de Ferrol, A Coruña, Spain;

${ }^{3}$ Department of Allergy, Hospital Infantil Universitario Niño Jesus, Madrid; Health Research Institute Princesa, Madrid, Spain; ARADyAL Research Network;

\section{ACKNOWLEDGEMENTS}

We thank our study participants and research colleagues for their support. We also thank Dr Benjamin Remington for his advice on the Interval-Censoring Survival Analysis.

\section{Funding:}

Clinical challenges in the SOCMA study were funded through grant funds awarded by Jon Moulton Charity Trust, UK Medical Research Council (ref MR/S036954/1), Sociedad Española de Alergología e Inmunología Clínica (SEAIC), Sociedad Española de Inmunología Clínica, Alergología y Asma Pediátrica (SEICAP) and Instituto de Salud Carlos III and FEDER funds for the ARADyAL research network (RD16/006/0026). RB is supported by a Río Hortega Research Contract through the Instituto de Salud Carlos III and the European Social Fund (ref CM20/00253). MVO was supported by a Marie Skłodowska-Curie actions - Research Fellowship funded by the Commission of the European Communities (reference: 656878). PJT is supported through the NIHR Biomedical Research Centre based at Imperial College Healthcare NHS Trust and Imperial College London. The views expressed are those of the author(s) and not necessarily those of the NHS, NIHR, or the Department of Health.

The funders of the study had no role in study design, data collection, data analysis, data interpretation or writing of the report. The corresponding author had full access to all the data in the study and had final responsibility for the decision to submit for publication.

\section{Competing interests}

All authors have completed the ICMJE uniform disclosure form at www.icmje.org/coi_disclosure.pdf and declare: grants from Jon Moulton Charity Trust, UK Medical Research Council, Spanish Society of Allergology and Clinical Immunology and Spanish Society of Paediatric Allergology, Asthma and Clinical Immunology. PJT reports additional grants from UK Medical Research Council, NIHR/Imperial BRC and UK Food Standards Agency during the conduct of the study; personal fees from UK Food Standards Agency, DBV Technologies, Aimmune Therapeutics, Allergenis, and ILSI Europe, outside the submitted work. RB reports funding from the Health Research Fund of Carlos III Health Institute (Spain), and honoraria for lectures from LETI Pharma. MVO reports additional research funding from the Health Research Fund of Carlos III Health Institute (Spain), and the FPIES Foundation. PRR reports funding from the Health Research Fund of Carlos III Health Institute, Foundation for Biomedical Research of the Niño Jesus University Children's 
Hospital, and reports honoraria for consultancy and/or advisory board and/or lectures from ALK-Abello, FAES Pharma, LETI Pharma, Merck, Aimmune Therapeutics, Allergy Therapeutics, MEDA Pharma and NovartisDC. All other authors declare no competing interests.

\section{REFERENCES}

1. Turner PJ, Baumert JL, Beyer K, Boyle RJ, Chan CH, Clark AT, et al. Can we identify patients at risk of life-threatening allergic reactions to food? Allergy 2016;71(9):1241-55.

2. Westerhout J, Baumert JL, Blom WM, Allen KJ, Ballmer-Weber B, Crevel RWR, et al. Deriving individual threshold doses from clinical food challenge data for population risk assessment of food allergens. J Allergy Clin Immunol. 2019 Nov;144(5):1290-1309.

3. Dano D, Remington BC, Astier C, Baumert JL, Kruizinga AG, Bihain BE, Taylor SL, Kanny G. Sesame allergy threshold dose distribution. Food Chem Toxicol. 2015 Sep;83:48-53.

4. Houben GF, Baumert JL, Blom WM, Kruizinga AG, Meima MY, Remington BC, Wheeler MW, Westerhout J, Taylor SL. Full range of population Eliciting Dose values for 14 priority allergenic foods and recommendations for use in risk characterization. Food Chem Toxicol. 2020 Dec;146:111831.

5. Petersen TH, Mortz CG, Bindslev-Jensen C, Eller E. Cow's milk allergic children-Can componentresolved diagnostics predict duration and severity? Pediatr Allergy Immunol. 2018 Mar;29(2):194-199.

6. Turner PJ, Custovic A. Life-threatening anaphylaxis to peanut - impossible to predict? J. Allergy Clin. Immunol. 2021 (in press).

\section{FIGURE LEGENDS}
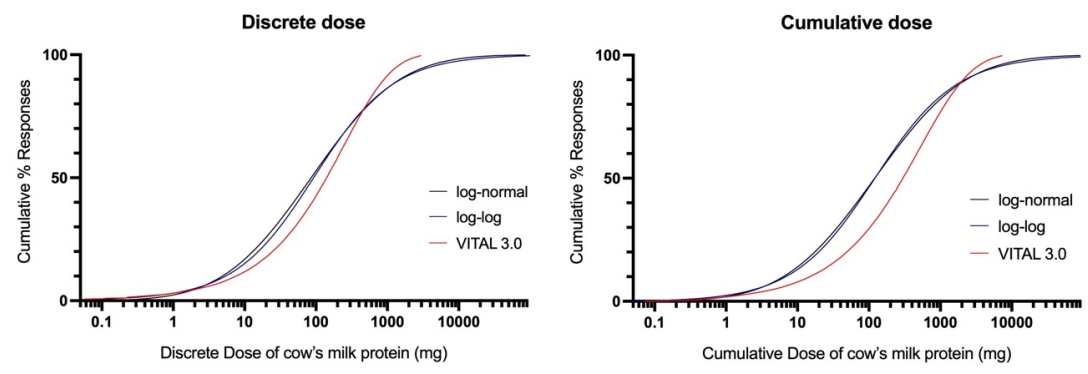

Figure 1. Eliciting dose curves from the model averaged population threshold dose distributions for cow's milk, based on discrete (A ) and cumulative (B ) dose datasets. Doses are expressed in mg cow's milk protein, and are compared to equivalent data reported by Houben et al used to inform VITAL 3.0 reference doses. $^{4}$

Table 1: Characteristics of the study population and predictors of anaphylaxis or eliciting dose

\begin{tabular}{lllllll}
\hline & $\begin{array}{l}\text { Overall } \\
\text { cohort } \\
(\mathbf{n}=\mathbf{9 8})\end{array}$ & $\begin{array}{l}\text { Anaphylaxis } \\
\text { Reaction at } \\
\text { DBPCFC }\end{array}$ & $\begin{array}{l}\text { Anaphylaxis } \\
\text { Reaction at } \\
\text { DBPCFC }\end{array}$ & $\begin{array}{l}\text { Anaphylaxis } \\
\text { Reaction at } \\
\text { DBPCFC }\end{array}$ & $\begin{array}{l}\text { Predictor of } \\
\text { eliciting } \\
\text { dose? }\end{array}$ & $\begin{array}{l}\text { Predictor of } \\
\text { eliciting } \\
\text { dose? }\end{array}$ \\
\hline & & $\begin{array}{l}\text { Anaphylaxis } \\
(\mathrm{n}=16)\end{array}$ & $\begin{array}{l}\text { Mild-moderate } \\
\text { reaction } \\
(\mathrm{n}=67)\end{array}$ & $\mathrm{p}$ value & $\begin{array}{l}\text { Correlation } \\
\text { (Spearman's }\end{array}$ & $\begin{array}{l}\text { Multivariate } \\
\text { analysis }\end{array}$ \\
Age (years) & $10(7.8,13)$ & $11(8,13.5)$ & $10(7,13)$ & $\mathrm{p}=0.62$ & $\begin{array}{l}\mathrm{R}) \\
\mathrm{r}_{\mathrm{s}}=0.09\end{array}$ \\
$\begin{array}{l}\text { Sex (Male) } \\
\begin{array}{l}\text { Previous } \\
\text { anaphylaxis } \\
\text { to cow's } \\
\text { milk }(\mathrm{CM})\end{array}\end{array}$ & $56(57 \%)$ & $9(56 \%)$ & $38(57 \%)$ & $\mathrm{p}=1.00$ & $\mathrm{p}=0.37$ & \\
\end{tabular}




\begin{tabular}{|c|c|c|c|c|c|c|}
\hline & $\begin{array}{l}\text { Overall } \\
\text { cohort } \\
(n=98)\end{array}$ & $\begin{array}{l}\text { Anaphylaxis } \\
\text { Reaction at } \\
\text { DBPCFC }\end{array}$ & $\begin{array}{l}\text { Anaphylaxis } \\
\text { Reaction at } \\
\text { DBPCFC }\end{array}$ & $\begin{array}{l}\text { Anaphylaxis } \\
\text { Reaction at } \\
\text { DBPCFC }\end{array}$ & $\begin{array}{l}\text { Predictor of } \\
\text { eliciting } \\
\text { dose? }\end{array}$ & $\begin{array}{l}\text { Predictor of } \\
\text { eliciting } \\
\text { dose? }\end{array}$ \\
\hline Asthma & $60(61 \%)$ & $9(56 \%)$ & $41(61 \%)$ & $\mathrm{p}=0.78$ & & \\
\hline Eczema & $60(61 \%)$ & $8(50 \%)$ & $43(64 \%)$ & $\mathrm{p}=0.39$ & & \\
\hline $\begin{array}{l}\text { Other food } \\
\text { allergy }\end{array}$ & $74(76 \%)$ & $12(75 \%)$ & $47(70 \%)$ & $\mathrm{p}=0.77$ & & \\
\hline $\begin{array}{l}\text { Total IgE } \\
(\mathrm{kUA} / \mathrm{L})\end{array}$ & $\begin{array}{l}576(289 \\
1153)\end{array}$ & $\begin{array}{l}447(229 \\
991)\end{array}$ & $\begin{array}{l}571(246, \\
1202)\end{array}$ & $\mathrm{p}=0.65$ & $\begin{array}{l}\mathrm{r}_{\mathrm{s}}=0.03 \\
\mathrm{p}=0.78\end{array}$ & \\
\hline $\begin{array}{l}\text { Specific IgE } \\
(\mathrm{kUA} / \mathrm{L}) \text { to: } \\
\text { CM protein } \\
\text { Casein }\end{array}$ & $\begin{array}{l}18.7(3.9, \\
59.6) 12.7 \\
(2.3,57.2)\end{array}$ & $\begin{array}{l}19.3(9.7 \\
49.8) 15.9 \\
(7.3,62.9)\end{array}$ & $\begin{array}{l}23.6(5.5, \\
83.1) 12.7 \\
(2.9,57.2)\end{array}$ & $\begin{array}{l}\mathrm{p}=0.81 \\
\mathrm{p}=0.78\end{array}$ & $\begin{array}{l}\mathrm{r}_{\mathrm{s}}=-0.63 \\
\mathrm{p}<0.001 \\
\mathrm{r}_{\mathrm{s}}=-0.63 \\
\mathrm{p}<0.001\end{array}$ & $\begin{array}{l}p=0.052 \\
p=0.018\end{array}$ \\
\hline $\begin{array}{l}\text { SPT wheal } \\
(\mathrm{mm}) \text { to: } \\
\text { CM protein } \\
\text { Casein }\end{array}$ & $\begin{array}{l}7(5,10) 6 \\
(4,9)\end{array}$ & $\begin{array}{l}7(6,9) 7.5 \\
(6,9)\end{array}$ & $\begin{array}{l}6.5(5,9) \\
14.26(4.5, \\
69.8)\end{array}$ & $\begin{array}{l}\mathrm{p}=0.42 \\
\mathrm{p}=0.22\end{array}$ & $\begin{array}{l}\mathrm{r}_{\mathrm{s}}=-0.23 \\
\mathrm{p}=0.025 \\
\mathrm{r}_{\mathrm{s}}=-0.43 \\
\mathrm{p}<0.001\end{array}$ & $\begin{array}{l}\mathrm{p}=0.19 \\
\mathrm{p}=0.007\end{array}$ \\
\hline $\begin{array}{l}\text { Eliciting dose } \\
\text { (cumulative, } \\
\text { mg protein) }\end{array}$ & $\begin{array}{l}143.5(43.5 \\
443.5)\end{array}$ & $\begin{array}{l}143.5(68.5, \\
443.5)\end{array}$ & $\begin{array}{l}143.5(43.5 \\
1443.5)\end{array}$ & $\mathrm{p}=0.80$ & $\mathrm{~N} / \mathrm{A}$ & $\mathrm{N} / \mathrm{A}$ \\
\hline
\end{tabular}

Data are median (interquartile range). P values calculated in GraphPad Prism (vs 9.0) using Mann-Whitney test for continuous data and Fisher Exact test for categorical data. 